\title{
Keeping the Competitive Edge of a Convention and Exhibition Center in MICE Environment: Identification of Event Attributes for Long-Run Success
}

\author{
Jaeyoung An ${ }^{1}$, Hany Kim ${ }^{2, *}$ (i) and Dongkeun Hur ${ }^{3}$ \\ 1 BEXCO, Busan 48060, Korea; jyan0066@naver.com \\ 2 Department of Tourism and Convention, Pusan National University, Busan 46241, Korea \\ 3 Gyeongju Hwabaek International Convention Center (HICO), Gyeongju 38116, Korea; \\ donggeun.huh@pusan.ac.kr \\ * Correspondence: hanykim@pusan.ac.kr
}

check for

updates

Citation: An, J.; Kim, H.; Hur, D. Keeping the Competitive Edge of a Convention and Exhibition Center in MICE Environment: Identification of Event Attributes for Long-Run Success. Sustainability 2021, 13, 5030. https://doi.org/10.3390/su13095030

Academic Editors: Charo Sadaba,

Mónica Herrero and

Patricia SanMiguel

Received: 2 April 2021

Accepted: 28 April 2021

Published: 30 April 2021

Publisher's Note: MDPI stays neutral with regard to jurisdictional claims in published maps and institutional affiliations.

Copyright: (c) 2021 by the authors. Licensee MDPI, Basel, Switzerland. This article is an open access article distributed under the terms and conditions of the Creative Commons Attribution (CC BY) license (https:// creativecommons.org/licenses/by/ $4.0 /)$.

\begin{abstract}
Understanding the weaknesses and strengths of event attributes plays a significant role in business survivability, specifically the meetings, incentives, conventions, and exhibitions (MICE) industry, in which the business environment is competitive. To be in business and survive long-term, service and product offerings must satisfy the needs of clients. In the case of the MICE industry, clients include event organizers, planners, and attendees. Thus, the IPA (importance-performance analysis) was conducted with hopes to provide valuable insight into the MICE industry to identify and evaluate their offering (attributes) that can assist Convention and Visitors Bureaus (CVBs) to establish better operational strategies that maintain their economic sustainability. Furthermore, this study also addressed the event planners and organizers' perceptions toward the environment and social sustainability, measuring the importance and performance of ecofriendly venues and the availability of disabled access, which showed neither significant importance nor performance. However, as the main purpose of the research was to examine the essential venue selection criteria based on the perceptional lens of the event organizer and planners to MICE operators on achieving business sustainability, the findings of this study provide strategical direction to establish, maintain, and improve their facility, service, and products. The study also finds that there are different needs depending on the types of event organizers and planners.
\end{abstract}

Keywords: MICE; IPA (importance-performance analysis); selection attribute; perception on sustainability; economic sustainability

\section{Introduction}

The meetings, incentives, conventions, and exhibitions (MICE) industry is one of the most rapidly growing segments in the hospitality and tourism sector and is a strong economic driver for local economies, having both direct and indirect multiplier effects [1-4]. The size of the economic effect generated by this industry is extensive because other key segments of tourism and hospitality such as accommodation, food and beverage, gaming and entertainment, transportation, local travel agencies, retail stores, and other establishments benefit from having convention events in their area [3]. Therefore, to boost economic benefits and create opportunities to further develop the economies of their destinations, countries and cities are investing in building event and convention facilities, or "purpose-built event and convention venues". Given the massive amount of financial investment in such facilities, it is important to have a Convention and Visitors Bureau (CVB) that hosts events all year round and attracts potential organizers and attendees to the event site, not only for a positive return on investment but also for the significant economic contributions these venues can provide for the region.

However, as the growth of the hospitality and tourism market increases, the competition among CVBs at different levels of destination (e.g., a site, city, region, country) has 
intensified so much that destinations across the globe are competing to be chosen as the venue for different types of events such as meetings, incentive trips, conventions, exhibitions, and conferences [5]. Thus, it is important for a CVB to understand the characteristics of its location and which of its specific attributes influence event organizers' decisions and potential attendees' intentions to engage an event [6-8].

It is also critical to consider the global trend and changes in MICE market environments in their operation. For example, implementing and integrating sustainable practices in everyday business have been recently emphasized for tourism sectors, with the United Nations Worlds Tourism Organization (UNWTO) calling for "a more sustainable future" by stressing the participation of all stakeholders in tourism and needs for sustainable development [9-11]. Although it is unlikely that the discussion of sustainability in tourism is new, research on sustainability in tourism has increased primarily in the past few years, but it is still lacking in the MICE environment [12,13]. In the discussion of implementing sustainable practices in the industry, it is necessary to understand the perception of event organizers and planners and whether they find sustainability important in choosing their event venue.

Before the COVID-19 outbreak in 2020 doomed the MICE industry, the market showed strong growth. The number of international association meetings doubled every 10 years between 1963 and 2010, followed by a 26\% growth between 2010 and 2019 [14]. In 2018, the UFI (Union des Foires Internationales in French, also known as the Global Association of the Exhibition Industry in English) reported that the number of venues with a minimum of $5000 \mathrm{~m}^{2}$ of indoor exhibition space worldwide increased by $1.6 \%$ from 1198 in 2011 to $1217^{2}$ in 2017 , while total available global indoor exhibition space increased by $7.6 \%$ from 32.3 million $\mathrm{m}^{2}$ to 34.7 million $\mathrm{m}^{2}$ during the same period [15]. The growth of the MICE industry is evident from these data; thus, it is critical for destinations to remain in dynamic competition if they want to reap the benefits of this growing market. In terms of market trends, there has been a growing preference for holding events in Asian-Pacific countries such as China, Japan, and South Korea rather than in the traditionally strong markets of Europe and the US. Because of this geographic trend, the factors influencing decision-makers' site selection criteria may differ. However, this newly emerging market and the venues with relatively large space in the markets need to be explored to determine how these regions can better respond to demand in this highly competitive business [13]. It is imperative that CVBs of purpose-built convention and exhibition centers understand the importance and performance of specific venue selection attributes [8] for the sustainable economic impact that centers will continue to generate revenue by ensuring a sustainable numbers of visitors and offering the services and products that organizers, planners, and attendees prefer (Tolkach and King [16]). As much as social and environmental sustainability, economic sustainability is critical for the survival of the tourism industry in many regions, cities, and countries [17].

Because of the importance of event attributes in the MICE industry and the lack of research about Asian-Pacific convention and exhibition venues [13], this study attempts to determine attributes that influence event planners' and decision-makers' choices when selecting venues in this area of the world, including planners and organizers' perception of sustainable practice as one of the attributes. More specifically, the research aims to capture the perceptions of various types of event organizers and planners who seek large purpose-built facilities for conference and meeting events. The Busan Exhibition and Convention Center (BEXCO) in Busan, South Korea, was chosen for this study as a model of a purpose-built facility in a newly emerging market [18]. BEXCO is a large-scale conference and exhibition center that contributed to building the MICE city brand [18]; however, the attributes that make event venues attractive destinations from event organizers and planners' perspectives were still not comprehensively explored. Importance-performance analysis (IPA) was employed to assess the importance and performance of the event venue attributes to provide optimal management strategies for the purpose-built facility. 


\section{Study Background}

\subsection{Impact of the MICE Industry}

This tourism and hospitality industry sector is generally characterized by its business and trade focus, although it also has public and leisure aspects, as well [19]. It is important to note that the terms "MICE industry", "business event", "business tourism", and "business travel" can be used interchangeably [20]. Because the MICE industry comprises a large part of local markets, a purpose-built facility can invigorate the local economy and increase tourism, enhancing the destination's image overall [21]. Because of these significant economic, social, and cultural impacts, both academics and practitioners have shown great interest in researching the MICE industry in various contexts and locations around the world [22].

Because of this industry's strong multiplier effect on local economies (e.g., restaurants, hotels, transportation, shopping, and attractions), its economic benefits have been analyzed by numerous researchers such as Braun [23], Kim and Chon [24], Kim, Chon, and Chung [25], and Mistilis and Dwyer [26]. Convention and exhibition visitors are known to be a high-spending market segment compared to other traditional types of tourists [1] Event participants spend more than double the money and, on average, stay 1.5 times longer than leisure tourists [22]. These convention visitors also participate in event-related or other activities before, during, and after events, which expands the economic impact beyond the event [25]. In regard to convention attendees' participation in activities in the destination, it was explained by Pinho and Marques [27] that great attention has been paid to Bleisure, or business leisure, in recent years and that business travelers seek for pleasure related to opportunities such as wine, food, and historical experiences. To take advantage of the benefits of MICE tourism, destinations at all levels must develop and improve their convention and event infrastructures [28] through substantial private financial support and government investment [22].

\subsection{MICE Venues and Issues}

One of the main areas of investment that governments are focused on is the construction of regional and city convention centers [1]. Local governments invest considerable money in building event venues to boost the hospitality and tourism industry and attract more visitors to the region [22,29].

While the purpose-built MICE venues have positive impacts, there are some concerns such as over-supply and profitability, which are considered key issues that can result in dramatic competition among the space suppliers [30]. Carlsen [31] also mentions issues that cities encounter and should consider when planning a convention center. The critical factors are "(1) feasibility and funding, (2) design, location, and construction, and (3) operations, management and marketing" [31] (p. 47). Besides venue size, Fenich [32] emphasizes management expertise as a critical characteristic for venue success. Convention centers are typically owned by either a government or private company and are managed in one of three ways: via "public, quasi-public, or private" means [32] (p. 152). Most large centers are managed by a quasi-public structure that tries to balance the needs of the community with those of the industry users and suppliers [32]. There are several reasons for having a public organization involved in the management and ownership of event venues. The popularity of a city as a tourist destination goes hand in hand with its convention center. When ownership of convention centers is given to a private party, the entity's priorities are to make a profit and cover high maintenance costs rather than to put community needs first. In general, public-run travel-promoting entities such as the CVBs or the DMOs (Destination Management Organizations) typically manage exhibition venues. Additionally, repeated government financial investment may be required for expansions and refurbishments as the demands of conventions and exhibitions change over time. Because the MICE business is global in nature, convention and exhibition venues tend to be influenced by uncontrollable risks such as economic recessions, uncertainty over the security of travel, and the threat of 
terrorism. Unlike public organizations, private corporations may not have the resources or expertise to handle such global-level crisis factors.

\subsection{MICE Attributes That Influence the Decision-Making Process}

As the MICE industry increasingly became an attractive travel segment in the global market, destinations quickly jumped into the game by building facilities and infrastructures to benefit from such business. It is vital to gain and maintain a competitive edge in the MICE environment. MICE destination tourism authorities and marketers must recognize the strengths and weaknesses of their destination so that they can prepare and employ proper market strategies. In that sense, having an understanding of which attributes of the destination and the convention and exhibition centers are influencing the event organizers and attendees' decisions is most critical [29,33-37].

Given the importance of the above-mentioned knowledge of the MICE industry, many researchers have attempted to identify the influential attributes in the decisionmaking process for site selection. While there are a variety of opinions among industry researchers, there is no consensus on which attributes are considered the most important [2]. A review of literature on this topic has shown that a destination's most significant attribute may differ depending on the characteristics of the location [38,39]. Although there is an abundance of research that examines the attributes of convention centers [3,8,29,33,40-43], there is not as much literature from the exhibition standpoint (e.g., [44-46]). Another stream of event venue research examines the perceptions of event planners and organizers $[29,33,47-49]$ as well as those who capture the views of attendees $[4,40,42,43]$. With the exception of Hinkin and Tracey [50], there are few research studies examining attributes from both the organizer and attendee perspectives.

Some key attributes that were found to be important to organizers and attendees were room availability, hotel service quality, safety and security, cleanliness/attractiveness, meeting room size, location of breakout room, cost, state-of-the-art audio-visual systems, entertainment facilities, attractive climate and lighting, and promotional support, particularly from the CVB $[4,43,48,49,51-53]$. Rather recently, sustainable practice was also identified as a crucial attribute for venue selection [54]. A review of the literature showed that there are only ever-increasing numbers of attributes for researchers to consider. Due to this complexity, researchers have attempted to categorize the attributes. For example, Oberoi and Hales [47] suggested two dimensions-service attributes as a functional service dimension and physical attributes as a technical dimension. Similarly, Go and Zhang [53] broadly classified attributes into convention facilities and destination environment-related categories. More elaborately, Oppermann and Chon [42] explained the attributes related to four factors: personal/business, association/conference, location, and intervening opportunities. Existing literature shows that the importance of the attributes varies depending on the destination setting and the perspectives of either or both the attendees and the organizers. Depending on the context of the research and setting of destinations, some attributes were found to be more important than others. Therefore, event marketers and organizers should continue to build their knowledge about the attributes of each existing market and also those pertaining to new emerging market environments.

\subsection{Study Purpose and Research Questions}

In spite of the considerable attention given by academic scholars to the factors that influence the event venue and destination selection decision-making process of both event organizers and attendees, little is known about the perspective of diverse types of organizers for different types of events. In particular, it was difficult to find research on the perceptions of different types of event organizers and planners for large purpose-built convention centers. In comparing the selection criteria of event planners and organizers, this study aims to capture the different perspectives of venue selection.

This study chose to evaluate Busan, South Korea, and its BEXCO as a purpose-built exhibition and convention center destination. Busan is the second-largest city in South 
Korea, and Lonely Planet listed it as the best city in Asia in 2018. Additionally, Busan is known for the Busan International Film Festival (BIFF), and it is in the running to host World Expo 2030. While the city has gained leisure travel popularity, little is known about its potential as a convention and event destination.

Thus, this study aims to explore whether there are significant differences among different types of events (e.g., exhibitions versus meetings, conventions versus other events) and how organizations and planners choose MICE event venues based on the attributes of both the facility and the destination. Furthermore, this study will examine to what extent purpose-built exhibition and convention centers meet the venue and destination attribute expectations of event organizers. In addition, this research will evaluate the level of importance and performance of event attributes when selecting a venue. The importance and performance of each event attribute will be compared using an IPA, then attributes will be compared with the types of events and hosting organizations.

This study proposes to answer the following research questions(RQs) about BEXCO:

$R Q 1$. Which venue attributes are highly valued in their perceived importance and performance?

RQ 2. Are there significant differences between the overall perceived importance and performance of the venue's selection attributes from the perspectives of MICE event planners?

$R Q 3$. Are there significant differences among the various types of events in terms of the level of importance of venue selection attributes?

$R Q 4$. Does the level of performance of the purpose-built event center generate significant differences in the types of events that are held there?

RQ 5. Are there significant differences among the six different types of organizations (professional exhibition organizer, professional conference organizer, association, governmental organization, general company, others) in terms of the level of importance and performance of the venue selection attributes?

\section{Methodology}

\subsection{Data Collection and Measurement}

The online survey questionnaire link (via SurveyMonkey) was sent to event organizers and planners who had prior experience hosting and planning events at least one or more times at BEXCO. The first email request was sent to 657 qualified event organizers and planners who were listed in BEXCO's in-house database and a reminder was sent the following week A total of 121 responded but after eliminating responses, 93 usable samples were retained. (see Table 1 for the detail). To obtain the perspectives of the different types of event organizers for this study, the researcher categorized the subjects into three groups: exhibition planners, meeting and conference planners, and other event planners.

Table 1. Survey Distribution and Collection.

\begin{tabular}{cccc}
\hline & & First E-Mail Request & Reminder \\
\hline \multirow{3}{*}{ Distribution } & Total e-mail account & $657(100 \%)$ & $666(100 \%)$ \\
& Delivered & $567(86 \%)$ & $574(86 \%)$ \\
& Error & $90(14 \%)$ & $92(14 \%)$ \\
& Opened & $334(51 \%)$ & $283(42 \%)$ \\
\hline \multirow{3}{*}{ Collection } & & Number & $\%$ \\
& Response & 121 & $18 \%$ \\
& Usable & 93 & $14 \%$ \\
& Invalid & 28 & $4 \%$ \\
\hline
\end{tabular}

The survey was completed by event organizers and planners who had prior experience hosting and planning events at least one or more times at BEXCO. To obtain the perspectives of the different types of event organizers for this study, the researcher categorized the subjects into three groups: exhibition planners, meeting and conference planners, and other 
event planners. Additionally, it should be noted that there were more specified types of organizations identified within the types of event organizers based on BEXCO's inhouse database during the experts' consulting on designing the survey: "professional exhibition organizer", "professional conference organizer", "association", "governmental organization", and "general company. Thus, survey respondents were also asked to identify among six choices including "other" and those who selected "other" were asked to write in how they identify themselves.

A web-based survey was conducted, consisting of six sections and a total of 26 questions. Sections 1 and 2 were about the characteristics of the organizations the respondents work for and the events the respondents have held, respectively. Section 3 consisted of 31 items and used a seven-point Likert scale to assess the level of importance of the venue selection attributes. Section 4 consisted of the same items as Section 3 but assessed the level of performance of the venue selection attributes based on organizers' experiences. Section 5 consisted of the respondents' overall satisfaction with the venue as well as their suggestions for its improvement. Finally, Section 6 contained questions about demographic information.

To elaborate, the list of venue selection attributes used in Sections 3 and 4 was adopted from previously published studies focusing on the selection attributes of large convention centers $[8,44]$. The attributes were mainly grouped into three categories: (1) venue and facility-related attributes, (2) staff and services, and (3) cost and other general attributes. The classification was based on Wu and Webber [8], who included 23 selection attributes of facilities and services, and Breiter and Milman's [44] distinction of seven facility services and 19 facility features. While in the designing and consulting stage, BEXCO staff concluded that the attributes could be grouped into facilities, service, and cost and more general related features considering the nature of convention business.

In addition, the selection of venue attributes for the survey was informed by five convention center staff members in Korea and designed to reflect the characteristics of a purpose-built exhibition and convention center. A total of 31 attributes were measured and divided into three groups: (1) venue and facility-related attributes, (2) staff and services attributes, and (3) costs and other general attributes. To measure the importance and performance of attributes and the satisfaction related to them, a seven-point Likert scale was employed using a range from 1 (not at all important/performance significantly under expectation/not at all satisfied) to 7 (very important/performance significantly over expectation/very satisfied).

\subsection{Data Analysis}

An IPA method was used because it is known to be effective, not only for presenting findings and suggesting strategies for improvement [55,56], but also for selecting tourism/event destinations [34]. Figure 1 shows a two-dimensional matrix divided into four quadrants that was constructed to provide a clear, visual representation of the findings and offer a potential strategic direction for the convention center to be competitive in the market. The matrix was constructed by plotting the actual mean values of the ratings for importance and performance.

Following Martilla and James's [57] framework, Wu and Shieh [58] explain the implications of the four quadrants of a performance/importance matrix as follows:

- Quadrant I (high performance/high importance) indicates the attributes that are major strengths and opportunities for gaining or maintaining a competitive advantage. The business strategy is "keep up the good work";

- Quadrant II (low performance/high importance) indicates a major weakness and that immediate attention for improvement is required for this area. "Concentrate here" is suggested as a management scheme to address data points this quadrant;

- Attributes that appear in Quadrant III (low performance/low importance) can be considered minor weaknesses that do not require additional efforts to resolve. "Low priority" is the managerial directive here; and 
- Quadrant IV (high performance/low importance) indicates over-emphasis, which can be considered a minor strength. Consequently, the resources in this quadrant should be deployed where they are needed. The management strategy is "possible overkill".

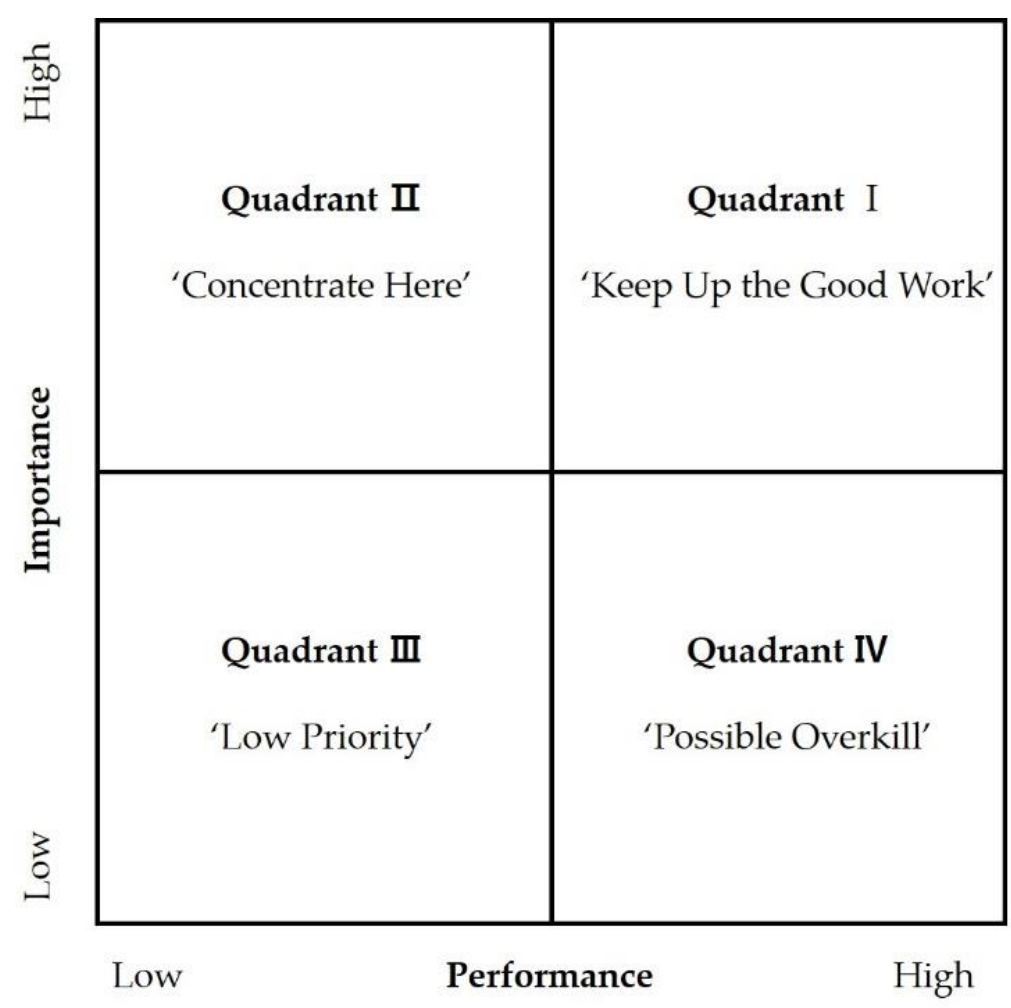

Figure 1. The original IPA framework. Source: Martilla and James [57].

In addition to the IPA, a frequency test, a $t$-test, a one-way between-groups analysis of variance (ANOVA), and an analysis of variance (ANOVA) with a post-hoc analysis were conducted to provide the respondents' demographic profiles and answer the research questions. Before using the attribute measurement for further analysis, its reliability was tested. The results of the reliability test are seen in Table 2 and imply suitable internal consistency reliability with both the importance and performance components based on the presence of a Cronbach alpha coefficient above 0.086 in all areas [59]. The reliabilities of attribute group classifications were provided as the group's classification was suggested by staff of the convention center.

Table 2. Reliability Test Results.

\begin{tabular}{ccccc}
\hline & Importance & \multicolumn{2}{c}{ Performance } \\
\hline & $\begin{array}{c}\text { Number of } \\
\text { Items }\end{array}$ & $\begin{array}{c}\text { Cronbach's } \\
\text { Alpha }\end{array}$ & $\begin{array}{c}\text { Number of } \\
\text { Items }\end{array}$ & $\begin{array}{c}\text { Cronbach's } \\
\text { Alpha }\end{array}$ \\
\hline Venue and facility-related attributes & 17 & 0.914 & 17 & 0.952 \\
Staff and service & 6 & 0.869 & 6 & 0.889 \\
Cost and other general attributes & 8 & 0.882 & 8 & 0.905 \\
\hline
\end{tabular}

\section{Findings}

\subsection{Respondent Profiles}

A total of 93 respondents completed and returned the survey. The profiles of the respondents by event and organizer type are shown in Table 3, and they were classified into six different types of organizations (see Table 4 ). Table 4 explains the specification of the organization types. Additionally, the profile indicated that 60 respondents (64.5\%) of 
the total respondents were male. Over half of the respondents (51\%) were in the age group 30-39 years old (Table 5).

Table 3. Types of Event Organizers.

\begin{tabular}{cccc}
\hline $\begin{array}{c}\text { Organization Type } \\
\text { (No. of Respondents) }\end{array}$ & Exhibition & Meeting and Conference & Other Event \\
\hline Professional exhibition organizer (14) & $14(56 \%)$ & $0(0.0 \%)$ & $0(0.0 \%)$ \\
Professional conference organizer (4) & $0(0.0 \%)$ & $4(7.3 \%)$ & $0(0.0 \%)$ \\
Association (20) & $5(20 \%)$ & $12(21.8 \%)$ & $3(23.1 \%)$ \\
Governmental organization (11) & $3(12 \%)$ & $7(12.7 \%)$ & $1(7.7 \%)$ \\
General company (33) & $2(8 \%)$ & $24(43.6 \%)$ & $7(53.8 \%)$ \\
Others (11) & $1(4 \%)$ & $8(14.5 \%)$ & $2(15.4 \%)$ \\
Total (93) & $25(26.9 \%)$ & $55(59.1 \%)$ & $13(14 \%)$ \\
\hline
\end{tabular}

Table 4. Types of Organization and Specifications.

\begin{tabular}{|c|c|}
\hline Organization Type & Specification \\
\hline $\begin{array}{l}\text { Professional exhibition } \\
\quad \text { organizer (14) }\end{array}$ & $\begin{array}{c}\text { A company that specializes in the organizing and managing of exhibitions, trade shows, } \\
\text { and similar events }\end{array}$ \\
\hline $\begin{array}{l}\text { Professional conference } \\
\text { organizer (4) }\end{array}$ & $\begin{array}{c}\text { A company that specializes in the organizing and managing of congresses, conferences, } \\
\text { seminars, and similar events }\end{array}$ \\
\hline Association (20) & An official group of people who have the same job, aim, or interest \\
\hline Governmental organization (11) & Official government organizations and institutions \\
\hline General company (33) & A company such as manufacturers, retailers, etc. \\
\hline $\begin{array}{c}\text { Other (11) } \\
\text { (Open-ended) }\end{array}$ & $\begin{array}{l}\text { Educational institution (3), publishing company (2), research institute, political party, } \\
\text { advertising agency, broadcasting company, newspaper, language school }\end{array}$ \\
\hline
\end{tabular}

Table 5. Profile of Respondents.

\begin{tabular}{|c|c|c|c|}
\hline \multicolumn{2}{|r|}{ Variables } & \multirow{2}{*}{$\frac{\text { Number of Respondents }}{60}$} & \multirow{2}{*}{$\frac{\text { Percent (\%) }}{64.5}$} \\
\hline & Male & & \\
\hline Gender & Female & 33 & 35.5 \\
\hline \multirow{4}{*}{ Age group } & 20-29 years old & 16 & 17.2 \\
\hline & 30-39 years old & 48 & 51.6 \\
\hline & 40-49 years old & 17 & 18.3 \\
\hline & 50 or older than 50 & 12 & 12.9 \\
\hline \multirow{4}{*}{ City working in } & Capital area (except Seoul) & 10 & 10.8 \\
\hline & Seoul & 40 & 43.0 \\
\hline & Busan or Kyongnam & 37 & 39.8 \\
\hline & Other regions & 6 & 6.5 \\
\hline \multirow{5}{*}{ Work experience } & Less than 1 year & 10 & 10.8 \\
\hline & $1-3$ years & 26 & 28.0 \\
\hline & $4-7$ years & 27 & 29.0 \\
\hline & 8-10 years & 10 & 10.8 \\
\hline & More than 10 years & 20 & 21.5 \\
\hline
\end{tabular}

\subsection{Results for Research Questions}

4.2.1. Highly Valued Attributes as Related to Perceived Importance and Performance

The top five attributes perceived to be the most important for BEXCO by event planners were: (1) "reasonable rent" with a mean score of 6.33, (2) "competence and responsiveness of staff" with a mean score of 6.30, (3) "accessibility and easy use of public transport" with a mean score of 6.22, (4) "friendly staff" with a mean score of 6.15, and (5) "heating and air-conditioning systems" with a mean score of 6.31 . 
In terms of performance attributes, the top five attributes that the respondents reported performed significantly over expectation were (1) "cleanliness and well-maintained facility" with a mean score of 5.77, (2) "size and quality of exhibition facility" with a mean score of 5.60, (3) "accessibility and availability for parking" with a mean score of 5.56, (4) "number, size, and quality of meeting room" with a mean score of 5.56, and (5) "reputation and image of the venue" with a mean score of 5.49. In contrast, "reasonable rent" was the attribute which performed most significantly under expectations, with a mean score of 4.29.

\subsubsection{Differences between Overall Importance and Performance}

A paired-sample $t$-test was conducted to identify whether there was a significant difference between perceived importance and actual performance at BEXCO in the ratings for event venue selection attributes. In a paired-sample $t$-test, when the probability $(\mathrm{p})$ value labeled Sig. (two-tailed) is less than 0.05 , it can be concluded that there is a significant difference between the two scores.

The $t$-test results indicated that there were significant differences between importance and performance in 27 out of 31 items (see Table 6). Of the 27 attributes, only four received a higher score in performance than importance. In other words, the level of performance was higher than the perceived level of importance for these four attributes: "simultaneous interpretation system", "language ability of staff", "attractions and entertainment opportunities", and "shopping opportunities and accessibility to shopping areas".

Table 6. Difference Levels between Importance and Performance.

\begin{tabular}{|c|c|c|c|c|c|c|c|}
\hline \multirow{2}{*}{ Attributes } & \multicolumn{2}{|c|}{$\begin{array}{c}\text { Level of } \\
\text { Importance }\end{array}$} & \multicolumn{2}{|c|}{$\begin{array}{c}\text { Level of } \\
\text { Performance }\end{array}$} & \multirow{2}{*}{$\begin{array}{c}\text { Mean } \\
\text { Difference } \\
\text { (I)-(P) }\end{array}$} & \multicolumn{2}{|c|}{$t$-Test } \\
\hline & Mean (I) & Std & Mean (P) & Std & & t-Value & $\begin{array}{l}\text { Sig. } \\
\text { (2-Tailed) }\end{array}$ \\
\hline Reasonable rent & 6.33 & 0.98 & 4.29 & 1.52 & 2.043 & 11.100 & 0.000 \\
\hline Overall cost & 5.97 & 1.15 & 4.43 & 1.38 & 1.538 & 8.940 & 0.000 \\
\hline Service quality offered by contractors & 5.98 & 1.22 & 4.72 & 1.45 & 1.258 & 7.165 & 0.000 \\
\hline Sound insulation and lighting systems & 6.09 & 0.99 & 5.15 & 1.27 & 0.935 & 6.807 & 0.000 \\
\hline Competence and responsiveness of staff & 6.30 & 1.06 & 5.39 & 1.29 & 0.914 & 6.656 & 0.000 \\
\hline $\begin{array}{c}\text { Proximity of the venue to local food } \\
\text { service facilities }\end{array}$ & 5.54 & 1.45 & 4.69 & 1.43 & 0.849 & 4.991 & 0.000 \\
\hline Heating and air-conditioning systems & 6.13 & 0.97 & 5.32 & 1.30 & 0.806 & 5.816 & 0.000 \\
\hline Accessibility and easy use of public transport & 6.22 & 1.06 & 5.44 & 1.26 & 0.774 & 5.692 & 0.000 \\
\hline Wire(less) Internet access & 5.77 & 1.25 & 5.03 & 1.48 & 0.742 & 4.377 & 0.000 \\
\hline $\begin{array}{l}\text { Financial and administrative support from } \\
\text { local authority and CVB }\end{array}$ & 5.41 & 1.57 & 4.68 & 1.30 & 0.731 & 3.929 & 0.000 \\
\hline Friendly staff & 6.15 & 1.04 & 5.44 & 1.35 & 0.710 & 4.932 & 0.000 \\
\hline Visibility and accuracy of directional signage & 5.84 & 1.11 & 5.16 & 1.13 & 0.677 & 5.145 & 0.000 \\
\hline $\begin{array}{c}\text { Adequacy of the venue's public space and } \\
\text { circulation area }\end{array}$ & 6.01 & 1.02 & 5.34 & 1.20 & 0.667 & 4.693 & 0.000 \\
\hline Various choices of food on-site & 5.22 & 1.44 & 4.57 & 1.46 & 0.645 & 3.289 & 0.001 \\
\hline State-of-the-art audio-visual equipment & 5.52 & 1.23 & 4.95 & 1.37 & 0.570 & 3.426 & 0.001 \\
\hline Number, size, and quality of meeting room & 6.12 & 1.16 & 5.56 & 1.18 & 0.559 & 4.027 & 0.000 \\
\hline $\begin{array}{l}\text { Proximity of the venue to accommodation } \\
\text { facilities available }\end{array}$ & 5.32 & 1.56 & 4.84 & 1.35 & 0.484 & 2.847 & 0.005 \\
\hline Reputation and image of the venue & 5.97 & 1.12 & 5.49 & 1.15 & 0.473 & 3.632 & 0.000 \\
\hline Safety and security & 5.49 & 1.37 & 5.02 & 1.23 & 0.473 & 3.149 & 0.002 \\
\hline Accessibility and availability of parking & 6.00 & 1.02 & 5.56 & 1.18 & 0.441 & 3.435 & 0.001 \\
\hline Size and quality of exhibition facility & 6.04 & 1.20 & 5.60 & 1.16 & 0.441 & 3.138 & 0.002 \\
\hline Quality of catering service & 5.17 & 1.40 & 4.76 & 1.24 & 0.409 & 2.739 & 0.007 \\
\hline Cleanliness and well-maintained facility & 6.11 & 0.98 & 5.77 & 1.04 & 0.333 & 3.312 & 0.001 \\
\hline Overall design and interior of facility & 5.59 & 1.06 & 5.34 & 1.26 & 0.247 & 1.699 & 0.093 \\
\hline Ecofriendly venue & 4.94 & 1.30 & 4.70 & 1.27 & 0.237 & 1.618 & 0.109 \\
\hline Loading dock accessibility & 5.01 & 1.68 & 4.86 & 1.29 & 0.151 & 0.818 & 0.416 \\
\hline Availability of facilities for disabled access & 4.72 & 1.53 & 4.68 & 1.25 & 0.043 & 0.252 & 0.802 \\
\hline
\end{tabular}


Table 6. Cont.

\begin{tabular}{|c|c|c|c|c|c|c|c|}
\hline \multirow{2}{*}{ Attributes } & \multicolumn{2}{|c|}{$\begin{array}{c}\text { Level of } \\
\text { Importance }\end{array}$} & \multicolumn{2}{|c|}{$\begin{array}{c}\text { Level of } \\
\text { Performance }\end{array}$} & \multirow{2}{*}{$\begin{array}{c}\begin{array}{c}\text { Mean } \\
\text { Difference }\end{array} \\
\text { (I)-(P) }\end{array}$} & \multicolumn{2}{|c|}{$t$-Test } \\
\hline & Mean (I) & Std & Mean (P) & Std & & t-Value & $\begin{array}{c}\text { Sig. } \\
\text { (2-Tailed) }\end{array}$ \\
\hline Simultaneous interpretation system & 4.08 & 1.75 & 4.63 & 1.23 & -0.559 & -3.012 & 0.003 \\
\hline Language ability of staff & 4.31 & 1.66 & 4.89 & 1.17 & -0.581 & -3.253 & 0.002 \\
\hline Attractions and entertainment opportunities & 4.34 & 1.69 & 5.08 & 1.31 & -0.731 & -4.208 & 0.000 \\
\hline $\begin{array}{c}\text { Shopping opportunities and accessibility to } \\
\text { shopping area }\end{array}$ & 4.08 & 1.63 & 5.25 & 1.22 & -1.172 & -7.068 & 0.000 \\
\hline
\end{tabular}

Note 1 . The mean difference is significant at the 0.05 level. Note 2 . The results were arranged in descending order of mean difference.

For this research based on a seven-point Likert scale, the grand mean scores of importance $(M=5.54)$ and performance $(M=5.05)$ for the pooled data were imposed on the plot as the vertical and horizontal lines of the crosshairs because most of the mean scores of the variables for both importance and performance were above the median $(M E D=4)$.

The IP matrix of the event venue selection attributes that appears as Figure 2 shows that the majority of spots were positioned in two quadrants. Thirteen spots $(41 \%)$ were found in the upper-right area (Quadrant I = High Importance/High Performance) and 12 spots $(38 \%)$ lay in the lower-left area (Quadrant III = Low Importance/Low Performance). Quadrants II and IV captured only five (16\%) and two items (6\%), respectively. Among the 31 spots (see Box 1), key 6 is plotted to the right of the horizontal line of the crosshairs with an importance mean score of 5.54. In this study, key 6 was considered to fall in both Quadrants II and III.

Box 1. Venue Selection Attributes Key.

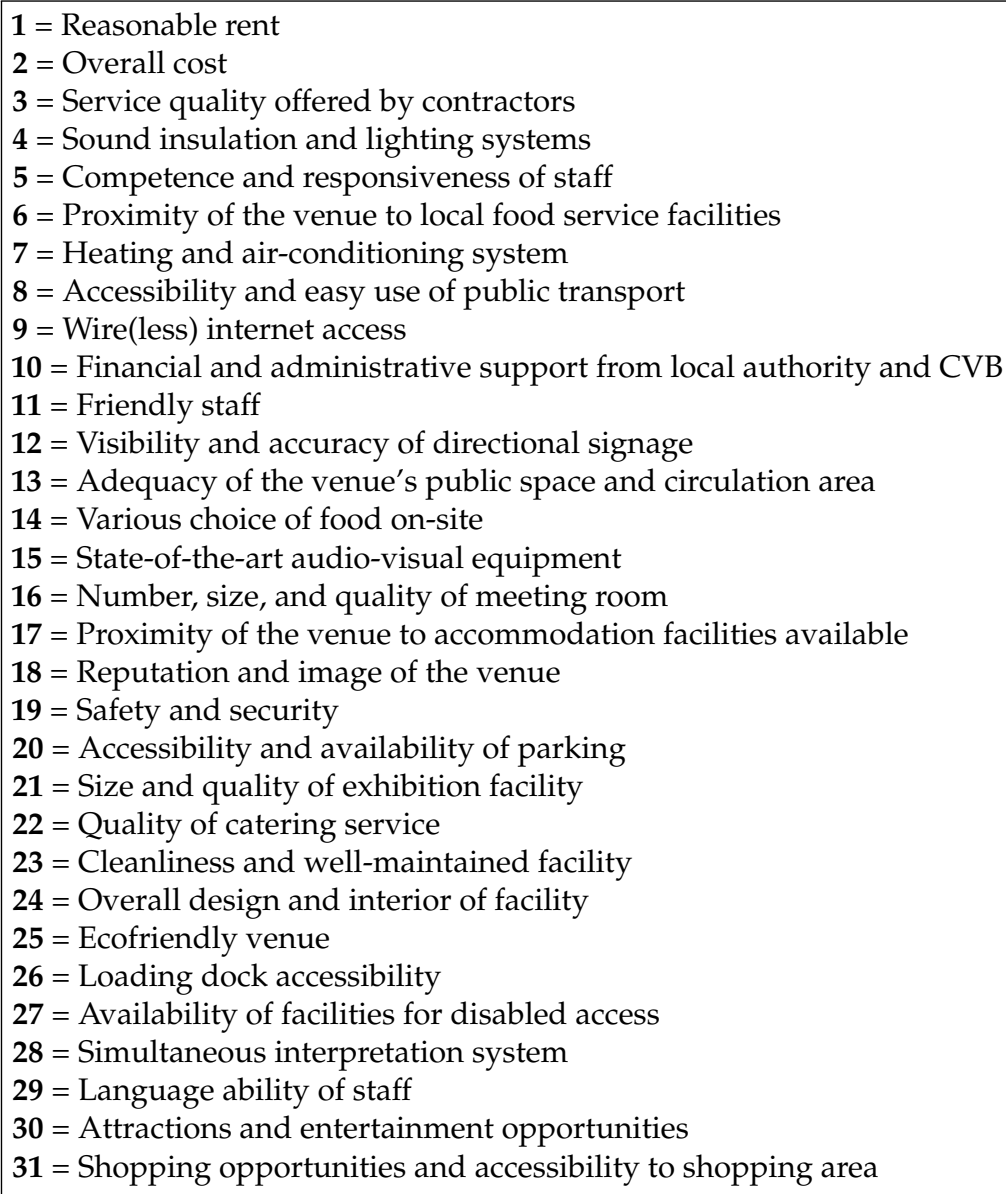




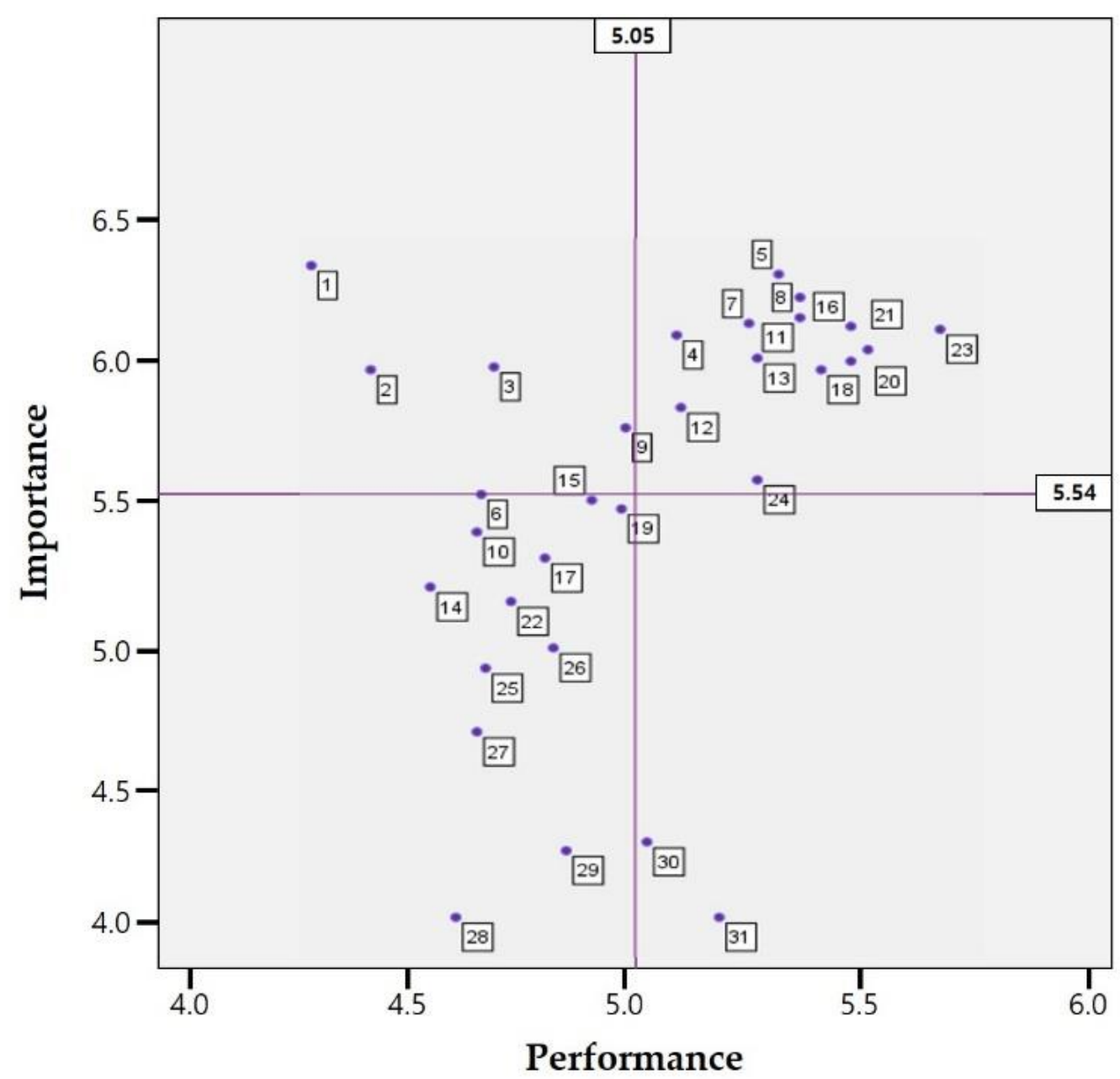

Figure 2. IP Matrix-BEXCO. Note. Key 6 is plotted right on the horizontal line of the crosshairs, which means it belongs to both Quadrant II and III.

According to the results of the IPA, overall performance at BEXCO could be interpreted as being good (having a grand mean score of 5.05) and being higher than the median ( $\mathrm{M}=4)$ on a seven-point Likert scale. All the mean scores of the 31 venue selection attributes fell above the median. However, compared to the importance of the attributes, the overall mean level of performance at BEXCO did not reach the mean level of importance.

While the major weaknesses where immediate action for improvement should be taken are in five areas, the major strengths of BEXCO consist of 13 items that meet the customers' needs and expectations.

\subsubsection{Differences in Importance among Different Types of Events}

An ANOVA with a post-hoc test was conducted to determine whether there were significant differences across the different types of events in the levels of importance and performance of the 31 event venue selection attributes. As seen in Table 7, the results revealed that there were significant differences in importance for four out of 31 variables across the three types of events ( $p$-values of less than 0.05 ). The four variables were "loading dock accessibility", "number, size, and quality of meeting room", "shopping opportunities and accessibility to shopping areas", and "reputation and image of the venue". Of the four variables, the "meeting and conference" group rated the highest for "number, size, and quality of meeting room", while "exhibition" rated the highest for the other three attributes. 
Table 7. Results of ANOVA of Venue Attributes by Event Type in the Perceived Importance Related to Perceived Importance.

\begin{tabular}{cccccccccc}
\hline \multirow{2}{*}{ Attributes } & \multicolumn{2}{c}{ Exhibition } & \multicolumn{2}{c}{ Meeting and Conference } & \multicolumn{3}{c}{ Other Event } & \multicolumn{2}{c}{ ANOVA } \\
\cline { 2 - 8 } & Mean & Std. & Mean & Std. & Mean & Std. & F & Sig. \\
\hline Loading dock accessibility & 6.04 & 1.369 & 4.69 & 1.698 & 4.38 & 1.325 & 7.549 & 0.001 \\
Number, size, and quality of meeting room & 5.52 & 1.584 & 6.44 & 0.788 & 5.92 & 1.115 & 6.214 & 0.003 \\
Shopping opportunities and accessibility to \\
shopping areas
\end{tabular}

Note. The mean difference is significant at the 0.05 level.

\subsubsection{Differences in Performance among Different Types of Events}

In terms of performance at BEXCO, significant differences among three groups were found in 11 of the 31 attributes (see Table 8). There were significant differences between the "exhibition" and "meeting and conference" groups in all 11 categories. Interestingly, without exception, the mean scores for "exhibition" were lower than those of "meeting and conference" in the 11 variables. More interestingly, the level of exhibition planners' perceived importance of the given attributes was highest with a mean score of 5.63. However, the level of performance was the lowest rated, with a mean score of 4.65. This signifies that exhibition planners were the least satisfied with their BEXCO event experience.

Table 8. Results of ANOVA of Venue Attributes by Event Type Related to the Performance at BEXCO.

\begin{tabular}{|c|c|c|c|c|c|c|c|c|}
\hline \multirow{2}{*}{ Attributes } & \multicolumn{2}{|c|}{ Exhibition } & \multicolumn{2}{|c|}{ Meeting and Conference } & \multicolumn{2}{|c|}{ Other Event } & \multicolumn{2}{|c|}{ ANOVA } \\
\hline & Mean & Std. & Mean & Std. & Mean & Std. & F & Sig. \\
\hline Service quality offered by contractors & 3.84 & 1.573 & 5.13 & 1.277 & 4.69 & 1.251 & 7.713 & 0.001 \\
\hline Overall design and interior of facility & 4.60 & 1.528 & 5.64 & 1.095 & 5.54 & 0.776 & 6.693 & 0.002 \\
\hline Heating and air-conditioning systems & 4.68 & 1.492 & 5.67 & 1.106 & 5.08 & 1.188 & 5.886 & 0.004 \\
\hline Competence and responsiveness of staff & 4.72 & 1.370 & 5.64 & 1.223 & 5.62 & 1.044 & 4.933 & 0.009 \\
\hline Wire(less) internet access & 4.32 & 1.547 & 5.38 & 1.340 & 4.92 & 1.498 & 4.853 & 0.010 \\
\hline Sound insulation and lighting systems & 4.60 & 1.323 & 5.45 & 1.152 & 4.92 & 1.320 & 4.459 & 0.014 \\
\hline $\begin{array}{c}\text { Adequacy of the venue's public space and } \\
\text { circulation area }\end{array}$ & 4.76 & 1.422 & 5.58 & 1.083 & 5.46 & 0.877 & 4.388 & 0.015 \\
\hline Number, size, and quality of meeting rooms & 5.00 & 1.354 & 5.80 & 1.061 & 5.62 & 1.044 & 4.218 & 0.018 \\
\hline State-of-the-art audio-visual equipment & 4.36 & 1.381 & 5.25 & 1.336 & 4.77 & 1.166 & 4.039 & 0.021 \\
\hline Cleanliness and well-maintained facility & 5.36 & 1.350 & 5.98 & 0.913 & 5.69 & 0.630 & 3.247 & 0.043 \\
\hline Accessibility and availability of parking & 5.08 & 1.525 & 5.78 & 0.994 & 5.54 & 0.967 & 3.165 & 0.047 \\
\hline
\end{tabular}

Note. The mean difference is significant at the 0.05 level.

4.2.5. Differences in the Levels of Importance and Performance of the Venue Selection Attributes among the Six Different Types of Organizations

An ANOVA with post-hoc test was conducted to identify whether there were significant differences among types of organizations in terms of the level of importance and performance of the 31 attributes (see Table 9). The six different organization types considered were professional exhibition organizer (further, exhibition org.), professional conference organizer (further, conference org.), association, governmental organization (further, gov. org), general company, and other.

The results of the ANOVA indicated there were significant differences in the level of importance of only three attributes across the six types of organizations at $p$-value of 0.05 . These three items are "number, size, and quality of meeting room", "attractions and entertainment opportunity", and "shopping opportunities and accessibility to shopping area". For "number, size, and quality of meeting room" ( $\mathrm{F}=3.253, p=0.010)$, there was a significant difference between the "professional exhibition organizer" category and the other five groups. The importance of "attractions and entertainment opportunity" $(\mathrm{F}=3.042, p=0.14)$ indicated a significant difference between "professional exhibition organizer" and "general company" where the mean score is very low. In the category of "shopping opportunities 
and accessibility to shopping areas", the mean score of "professional exhibition organizer" $(\mathrm{M}=4.86)$ is significantly different from that of "general company" $(\mathrm{M}=3.39)$, although the mean scores of all groups were observed to be relatively low (below 5.00).

Table 9. Results of ANOVA of Perceived Importance of Venue Attributes by Organization Type.

\begin{tabular}{ccccccccc}
\hline & \multicolumn{4}{c}{ Mean } & \multicolumn{3}{c}{ ANOVA } \\
\cline { 2 - 8 } Attributes & Exh. Org. & Conf. Org. & Assoc. & Gov. Org. & $\begin{array}{c}\text { General } \\
\text { Company }\end{array}$ & Others & F & Sig. \\
\hline $\begin{array}{c}\text { Number, size, and quality of } \\
\text { meeting room }\end{array}$ & 5.07 & 6.75 & 6.25 & 6.36 & 6.21 & 6.45 & 3.253 & 0.010 \\
$\begin{array}{c}\text { Attractions and } \\
\text { entertainment opportunities }\end{array}$ & 5.07 & 4.75 & 4.80 & 4.00 & 3.58 & 5.09 & 3.042 & 0.014 \\
$\begin{array}{c}\text { Shopping opportunities and } \\
\text { accessibility to shopping areas }\end{array}$ & 4.86 & 4.50 & 4.40 & 3.91 & 3.39 & 4.55 & 2.383 & 0.045 \\
\hline
\end{tabular}

Note. The mean difference is significant at the 0.05 level.

As shown in Table 10, the results of the ANOVA identified differences in the performance attributes at BEXCO across types of organizations which indicated that there were significant differences in nine out of 31 attributes. The nine attributes in question are "access to wireless internet", "service quality offered by contractors", "reasonable rent", "heating and air-conditioning system", "accessibility and availability for parking", "overall cost", "loading dock accessibility", "state-of-the-art audio-visual equipment", and "overall design and interior of facility".

Table 10. Results of ANOVA of Performance of Venue Attributes by Organization Type at BEXCO.

\begin{tabular}{|c|c|c|c|c|c|c|c|c|}
\hline \multirow[b]{2}{*}{ Attributes } & \multicolumn{6}{|c|}{ Mean } & \multicolumn{2}{|c|}{ ANOVA } \\
\hline & Exh. Org. & Conf. Org. & Assoc. & Gov. Org. & $\begin{array}{l}\text { General } \\
\text { Company }\end{array}$ & Others & F & Sig. \\
\hline Reasonable rent & 3.71 & 2.50 & 3.85 & 4.64 & 4.61 & 5.18 & 3.383 & 0.008 \\
\hline State-of-the-art audio-visual equipment & 4.36 & 4.00 & 4.55 & 5.00 & 5.24 & 5.82 & 2.655 & 0.028 \\
\hline Overall cost & 4.07 & 2.75 & 4.10 & 4.82 & 4.58 & 5.27 & 2.964 & 0.016 \\
\hline Service quality offered by contractors & 3.64 & 3.75 & 5.00 & 4.82 & 4.76 & 5.73 & 3.536 & 0.006 \\
\hline Overall design and interior of facility & 4.64 & 4.75 & 5.25 & 5.00 & 5.64 & 6.09 & 2.541 & 0.034 \\
\hline Heating and air-conditioning systems & 4.64 & 4.00 & 5.15 & 5.18 & 5.79 & 5.73 & 3.083 & 0.013 \\
\hline Accessibility and availability of parking & 4.64 & 4.75 & 5.70 & 6.00 & 5.70 & 5.91 & 2.986 & 0.016 \\
\hline Wire(less) internet access & 4.21 & 3.25 & 5.10 & 4.82 & 5.30 & 6.00 & 3.720 & 0.004 \\
\hline Loading dock accessibility & 4.71 & 4.25 & 4.15 & 4.82 & 5.21 & 5.55 & 2.787 & 0.022 \\
\hline
\end{tabular}

Note. The mean difference is significant at the 0.05 level.

\section{Discussion}

\subsection{Theoretical Contributions}

It is imperative that convention and exhibition center management teams understand the importance and performance of specific event venue selection attributes in these times of intense global venue competition. This research explored the relationship between event types and attributes that influence venue selection as well as host organization types in the MICE industry. Furthermore, this research conducted an IPA to examine to what extent the purpose-built exhibition and convention center meets event planners' expectations.

This study categorized the event types as exhibitions, meetings, and other events to illustrate the differences in their evaluation of venue attributes. The findings indicated that there were distinctive gaps in terms of the importance and performance ratings for loading dock accessibility and meeting room facilities, which clearly shows that the event type determines attribute-based decisions when selecting a venue. It is understandable that loading dock accessibility would be an important attribute for exhibition planners because they have objects to load and install, while meeting room facilities would be critical to 
meeting conference planners. Specifically, the importance of meeting rooms was supported by the findings of Hinkin and Tracey [50] and Oppermann [48], which showed that meeting organizers find meeting room facilities to be a critical factor in venue choice.

Unfortunately, the findings showed that actual performance of attributes at BEXCO did not meet the needs and expectations of event planners. The attributes "competence and responsiveness of staff" and "reasonable rent" were ranked in the top five event attributes in terms of importance; however, those same attributes did not seem to impress event organizers from the performance perspective. The findings reflect existing research by MalekMohammadi and Mohamed [40], Oppermann [48], and others, for example, that shows that cost is an important factor when considering a venue choice. With the exception of Hultsman [45] and Kim and Chon [24], few studies illustrate the importance of service capacity. Further research by Hinkin and Tracey [50] and Robinson and Callan [60] illustrate service providers' competence as one of the important factors.

There are also some interesting findings that show that meeting planners were more satisfied than exhibition planners with BEXCO, which could be attributed to the fact that the venue and facilities are well established for meetings and conferences or that the convention center allocates more resources and efforts for meetings than exhibitions with careful reading of the results. This finding suggests that each stakeholder has different perspectives and needs for destinations and venues to be a success. DMOs need to account for the opinions of all stakeholders. This perspective aligns with the results of the difference analysis across the six types of organizations. With regard to cost being an important factor for a venue choice, professional conference organizers seem to be the most sensitive to cost and price.

Additionally, one important aspect that deserves the attention of the MICE industry is sustainable practice. In terms of general tourism, sustainability has become of utmost importance. As a matter of fact, the United Nations World Tourism Organization (UNWTO) has recommended that all tourism sectors implement a sustainable strategy and provided directions and best practices on this topic by launching and running a SDGs4Tourism session on UNWTO's official website [61]. In this study, event organizers did not seem to place importance on sustainable practices. Therefore, further research about sustainable practices in the MICE industry is called for, at minimum in regards to BEXCO and the Asia-Pacific region in general.

\subsection{Practical Implications}

The findings of this study will help venue management and owners better understand which event attributes to offer organizers. More specifically, the results of this study determined what kinds of attributes different types of event organizers are seeking when considering their venue selections. For this specific reason, the IPA was effective because it identified areas to strengthen and improve for increased business opportunities. The results of this study's analyses serve as guide for building a strategy for BEXCO to be a successful purpose-built event and convention center.

In terms of the IPA results, event organizers' overall evaluation of all attributes at BEXCO were deemed to be positive. However, the venue did not meet the same importance expectations that event organizers perceived it would. Considering that BEXCO was relatively new when this study was conducted, an achievement of 13 attributes of strength is impressive. Other areas for improvement were suggested by an IPA matrix, which identified the following as major weaknesses of BEXCO: reasonable rent, overall cost, service quality offered by contractors, proximity of venue to local food service facilities, and availability of internet access. In-depth interviews with event organizers who have used BEXCO in the past may be needed for the event venue to improve in these areas. Moreover, from a managerial perspective, BEXCO could improve service quality by operating more in-depth staff training sessions. The center's management team should also note that people's valuation of money is influenced by the value they perceive in a potential investment. Therefore, if management can reduce prices and costs, they should 
consider improvements to service and destination characteristics. If event organizers and attendees are satisfied with the services they receive and appreciate the locale as a popular tourist destination, they are increasingly likely to find more value in the costs they pay. Overall, this study demonstrated that why identifying attributes and its importance and performance matters to other destination and venue planners and authorities. IPA shows the clear direction of the strategy building.

\subsection{Limitations and Future Recommendations}

While this study attempted to capture the different perspectives of event facility stakeholders and employed the best resources available at the time of investigation to do so, it is not lacking in limitations. It used the same attributes that were already proven to be valid based on multiple previous studies on this topic. However, because the destination setting of this study differed, a pretest could have been conducted to identify attributes that are strictly related the South Korean destination. By having this additional pretest stage, new attributes directly related to the BEXCO setting could have been analyzed in more detail. Therefore, it is suggested that future studies conduct focus group interviews of academic scholars and professional event organizers who understand the characteristics of this destination to identify new attributes for investigation.

One other limitation of this study is that the representation of event organizers by type was imbalanced-there were more meeting and conference groups than exhibition groups in the sample population. However, because this study was exploratory and adequate for conducting the IPA, this limitation should be considered minor. It definitely would have been better to have captured an even number of voices (and more of them) from the different groups. Therefore, a future study should include more event organizers. Unfortunately, this study examined the perspective of event organizers only. It is recommended that event attendees' perspectives be considered in future studies to better understand an event venue's strengths and weaknesses. Finally, it is important to note that this study did not consider event type subgroups. For example, exhibitors of art and commercial products most likely require different event attributes. Therefore, an additional future study could compare the event needs of different types of exhibitors.

Additionally, the study was conducted before COVID-19. There are event facilities features that are deemed to be important during COVID-19—such as having and incorporating COVID-19 safety guidelines, ventilation systems, sensitization equipment, testing facilities, and WTTC's safety stamp — that were not considered. Thus, a future study could aim to identify the important attributes to consider during COVID-19 and any pandemic situation.

Author Contributions: Conceptualization, J.A.; methodology, J.A.; software, D.H.; validation, J.A. and H.K.; formal analysis, D.H.; investigation, J.A.; resources, D.H.; data curation, J.A.; writing—original draft preparation, J.A.; writing-review and editing, H.K.; visualization, D.H.; supervision, H.K.; project administration, H.K.; funding acquisition, H.K. All authors have read and agreed to the published version of the manuscript.

Funding: This research was supported by 2020 BK21 FOUR Program of Pusan National University and the BB21+ Project in 2021.

Institutional Review Board Statement: Not Applicable.

Informed Consent Statement: Not Applicable.

Data Availability Statement: Data sharing not applicable.

Conflicts of Interest: The authors declare no conflict of interest.

\section{References}

1. Alananzeh, O.; Al-Badarneh, M.; Al-Mkhadmeh, A.; Jawabreh, O. Factors influencing MICE tourism stakeholders' decision making: The case of Aqaba in Jordan. J. Conv. Event Tour. 2019, 20, 24-43. [CrossRef]

2. Clark, J.D.; McCleary, K.W. Influencing associations' site-selection process. Cornell Hotel Restaur. Adm. Q. 1995, 36, 5-68. [CrossRef] 
3. Elston, K.; Draper, J. A Review of Meeting Planner Site Selection Criteria Research. J. Conv. Event Tour. 2012, 13, 203-220. [CrossRef]

4. Fenich, G.G. Towards a conceptual framework for assessing community attractiveness for conventions. J. Conv. Exhib. Manag. 2001, 3, 45-64. [CrossRef]

5. DiPietro, R.B.; Breiter, D.; Rompf, P.; Godlewska, M. An exploratory study of differences among meeting and exhibition planners in their destination selection criteria. J. Conv. Event Tour. 2008, 9, 258-276. [CrossRef]

6. Montgomery, R.J.; Strick, S.K. Meetings, Conventions, and Expositions: An Introduction to the Industry; John and Wiley and Sons: Hoboken, NJ, USA, 1994; ISBN 978-0-471-28439-0.

7. Vogt, C.A.; Roehl, W.S.; Fesenmaier, D.R. Understanding planners' use of meeting facility information. Hosp. Res. J. 1994, 17, 119-130. [CrossRef]

8. Wu, A.; Weber, K. Convention center facilities, attributes and services: The delegates' perspective. Asia Pac. J. Tour. Res. 2005, 10, 399-410. [CrossRef]

9. UNWTO UNWTO and IFC Partner to Facilitate Green Investments for Tourism's Sustainable Future. Available online: https: //www.unwto.org/news/unwto-and-ifc-partner-to-facilitate-green-investments-for-tourisms-sustainable-future (accessed on 2 April 2021).

10. UNWTO. Tourism and the Sustainable Development Goals-Good Practices in the Americas; World Tourism Organization: Madrid, Spain, 2018; ISBN 9789284419685.

11. UNEP and UNWTO. Making Tourism More Sustainable-A Guide for Policy Makers; 2005 (In English). Available online: https://wedocs.unep.org/bitstream/handle/20.500.11822/8741/-Making\%20Tourism\%20More\%20Sustainable_\%20A\%20 Guide\%20for\%20Policy\%20Makers-2005445.pdf?sequence=3\&isAllowed=y (accessed on 26 May 2015).

12. Buathong, K.; Lai, P.C. Perceived attributes of event sustainability in the MICE industry in Thailand: A viewpoint from governmental, academic, venue and practitioner. Sustainability 2017, 9, 1151. [CrossRef]

13. Kim, K.; Ko, D. How to Build a Sustainable MICE Environment Based on Social Identity Theory. Sustainability 2020, $12,7166$. [CrossRef]

14. International Congress and Convention Association the International Association Meetings Market 2019. Available online: https: / / www.iccaworld.org/knowledge/article.cfm?artid=701 (accessed on 2 April 2021).

15. UFI UFI. World Map of Exhibition Vunues (2017 Edition, Revised December 2018). Available online: https://www.ufi.org/ archive-research/ufi-world-map-of-exhibition-venues-2017-edition-revised-december-2018/ (accessed on 7 September 2020).

16. Tolkach, D.; King, B. Strengthening Community-Based Tourism in a new resource-based island nation: Why and how? Tour. Manag. 2015, 48, 386-398. [CrossRef]

17. Joun, H.-J.; Kim, H. Productivity Evaluation of Tourism and Culture for Sustainable Economic Development: Analyzing South Korea's Metropolitan Regions. Sustainability 2020, 12, 2912. [CrossRef]

18. Ahn, Y.J.; Kim, I.; Lee, T.J. Exploring visitor brand citizenship behavior: The case of the 'MICE city Busan', South Korea. J. Destin. Mark. Manag. 2016, 5, 249-259. [CrossRef]

19. Allen, J.; O'toole, W.; Harris, R.; McDonnell, I. Festival and Special Event Management, 5th ed.; Wiley\& Sons: Hoboken, NJ, USA, 2010.

20. Davidson, R.; Cope, B. Business Travel: Conferences, Incentive Travel, Exhibitions, Corporate Hospitality and Corporate Travel; Pearson Education: London, UK, 2003; ISBN 0582404444.

21. Chen, H.C.; Chiou, C.Y.; Yeh, C.Y.; Lai, H.L. A study of the enhancement of service quality and satisfaction by Taiwan MICE service project. Procedia Soc. Behav. Sci. 2012, 40, 382-388. [CrossRef]

22. Lee, C.-K.; Lee, M.; Yoon, S.-H. Estimating the economic impact of convention and exhibition businesses, using a regional input-output model: A case study of the Daejeon Convention Center in South Korea. Asia Pac. J. Tour. Res. 2013, 18, 330-353. [CrossRef]

23. Braun, B.M. The economic contribution of conventions: The case of Orlando, Florida. J. Travel Res. 1992, 30, 32-37. [CrossRef]

24. Kim, S.S.; Chon, K. An economic impact analysis of the Korean exhibition industry. Int. J. Tour. Res. 2009, 11, 311-318. [CrossRef]

25. Kim, S.S.; Chon, K.; Chung, K.Y. Convention industry in South Korea: An economic impact analysis. Tour. Manag. 2003, 24, 533-541. [CrossRef]

26. Mistilis, N.; Dwyer, L. Tourism gateways and regional economies: The distributional impacts of MICE. Int. J. Tour. Res. 1999, 1, 441-457. [CrossRef]

27. Pinho, M.; Marques, J. The bleisure tourism trend and the potential for this business-leisure symbiosis in Porto. J. Conv. Event Tour. 2021, 1-16. [CrossRef]

28. Kay, A.L.K. China's convention and exhibition center boom. J. Conv. Event Tour. 2005, 7, 5-22. [CrossRef]

29. Crouch, G.I.; Del Chiappa, G.; Perdue, R.R. International convention tourism: A choice modelling experiment of host city competition. Tour. Manag. 2019, 71, 530-542. [CrossRef]

30. Sanders, H.T. Convention mythology. J. Conv. Event Tour. 2005, 6, 99-143. [CrossRef]

31. Carlsen, J. Issues in dedicated convention center development with a case study of the Perth Convention and Exhibition Center, Western Australia. J. Conv. Event Tour. 2005, 6, 45-61. [CrossRef]

32. Fenich, G.G. Convention center ownership and management: The case of the United States. In Convention Tourism: International Research and Industry Perspectives; Haworth Hospitality Press: New York, NY, USA, 2002; pp. 139-154. 
33. Jo, D.; Park, H.; Choe, Y.; Kim, D. Destination-selection attributes for international association meetings: A mixed-methods study. J. Destin. Mark. Manag. 2019, 13, 61-72. [CrossRef]

34. Whitfield, J.; Webber, D.J. Which exhibition attributes create repeat visitation? Int. J. Hosp. Manag. 2011, 30, 439-447. [CrossRef]

35. Jago, L.K.; Deery, M.; Jago, L.K.; Deery, M. Relationships and Factors Influencing Convention Relationships and Factors Influencing Convention Decision-Making. J. Conv. Exhib. Manag. 2008, 0148. [CrossRef]

36. Lee, H.; Lee, J. An exploratory study of factors that exhibition organizers look for when selecting convention and exhibition centers selecting convention and exhibition centers. J. Travel Tour. Mark. 2017, 34, 1001-1017. [CrossRef]

37. Siu, N.Y.; Yim, P.; Wan, K.; Dong, P. The impact of the servicescape on the desire to stay in convention and exhibition centers: The case of Macao. Int. J. Hosp. Manag. 2012, 31, 236-246. [CrossRef]

38. Weber, K.; Chon, K.-S. Convention Tourism: International Research and Industry Perspectives; Psychology Press: Hove, UK, 2002; ISBN 0789012847.

39. Fenich, G.G.; Bordelon, B.M. Is there an optimal type of ownership and organizational structure when developing convention and entertainment facilities? J. Conv. Event Tour. 2008, 9, 182-198. [CrossRef]

40. MalekMohammadi, A.; Mohamed, B. Convention decision-making modeling. Int. J. Trade Econ. Financ. 2010, 1, 54-56. [CrossRef]

41. Nelson, R.; Rys, S. Convention site selection criteria relevant to secondary convention destinations. J. Conv. Exhib. Manag. 2000, 2, 71-82. [CrossRef]

42. Oppermann, M.; Chon, K.-S. Convention participation decision-making process. Ann. Tour. Res. 1997, 24, 178-191. [CrossRef]

43. Zhang, H.Q.; Leung, V.; Qu, H. A refined model of factors affecting convention participation decision-making. Tour. Manag. 2007, 28, 1123-1127. [CrossRef]

44. Breiter, D.; Milman, A. Attendees' needs and service priorities in a large convention center: Application of the importanceperformance theory. Tour. Manag. 2006, 27, 1364-1370. [CrossRef]

45. Hultsman, W. From the eyes of an exhibitor: Characteristics that make exhibitions a success for all stakeholders. J. Conv. Exhib. Manag. 2001, 3, 27-44. [CrossRef]

46. Jin, X.; Bauer, T.; Weber, K. China's second-tier cities as exhibition destinations. Int. J. Contemp. Hosp. Manag. 2010, $22,552-571$. [CrossRef]

47. Oberoi, U.; Hales, C. Assessing the quality of the conference hotel service product: Towards an empirically based model. Serv. Ind. J. 1990, 10, 700-721. [CrossRef]

48. Oppermann, M. Convention destination images: Analysis of association meeting planners' perceptions. Tour. Manag. 1996, 17, 175-182. [CrossRef]

49. Renaghan, L.M.; Kay, M.Z. What meeting planners want: The conjoint-analysis approach. Cornell Hotel Restaur. Adm. Q. 1987, 28, 66-76. [CrossRef]

50. Hinkin, T.R.; Tracey, J.B. The Service Imperative: Factors Driving Meeting Effectiveness: More than any other factor, service drives satisfaction ratings for meeting participants. Cornell Hotel Restaur. Adm. Q. 2003, 44, 17-26. [CrossRef]

51. Comas, M.; Moscardo, G. Understanding associations and their conference decision-making processes. J. Conv. Exhib. Manag. 2005, 7, 117-138. [CrossRef]

52. Crouch, G.I.; Brent Ritchie, J.R. Convention site selection research: A review, conceptual model, and propositional framework. J. Conv. Exhib. Manag. 1997, 1, 49-69. [CrossRef]

53. Go, F.; Zhang, W. Applying importance-performance analysis to Beijing as an international meeting destination. J. Travel Res. 1997, 35, 42-49. [CrossRef]

54. Draper, J.; Dawson, M.; Casey, E. An exploratory study of the importance of sustainable practices in the meeting and convention site selection process. J. Conv. Exhib. Manag. 2011, 12, 153-178. [CrossRef]

55. Azzopardi, E.R. Nash A critical evaluation of importance-performance analysis. Tour. Manag. 2013, 35, 222-333. [CrossRef]

56. Oh, H. Revisiting importance-performance analysis. Tour. Manag. 2001, 22, 617-627. [CrossRef]

57. Martilla, J.A.; James, J.C. Importance-performance analysis. J. Mark. 1977, 41, 77-79. [CrossRef]

58. Wu, H.-H.; Shieh, J.-I. The development of a confidence interval-based importance-performance analysis by considering variability in analyzing service quality. Expert Syst. Appl. 2009, 36, 7040-7044. [CrossRef]

59. Hair, J.; Black, W.C.; Babin, B.J.; Anderson, R.E. Multivariate Data Analysis: A Global Perspective, 7th ed.; Pearson Education Limited: London, UK, 2009.

60. Robinson, L.S.; Callan, R.J. UK conference delegates' cognizance of the importance of venue selection attributes. J. Conv. Exhib. Manag. 2005, 7, 77-95. [CrossRef]

61. UNWTO TOURISM 4 SDGs. Available online: https://www.unwto.org/tourism4sdgs (accessed on 2 April 2021). 